\title{
PENERAPAN PEMBAGIAN HARTA WARISAN DI ANTARA AHLI WARISNYA DZAWIL FURUD MENUNJUKKAN BAHWA ANGKA PEMBILANG LEBIH BESAR DARI ANGKA PENYEBUT PASAL 192 KOMPILASI HUKUM ISLAM (KHI)
}

\author{
Syuhada' \\ Institut Agama Islam Bani Fattah Jombang, Indonesia \\ Syuhada@iaibafa.ac.id
}

Abstract: Islamic inheritance, Farâ'idh or Islamic inheritance regulates various matters in the distribution of inheritance to those entitled to receive it on the basis of the provisions stipulated in the Qur'an, the sunnah of the Holy Prophet. and scholars agreement. The maker of farâ'idh or Islamic inheritance is Allah. The object is a relic. the goal can be to give heir rights to inheritance in accordance with the guidelines of Islamic law based on the Al-Qur'an, Al-Hadit, Al-'Ijmâ and Al-Qiyâs. Inheritance in Islam contains the rule of law regarding the transfer of corpses property definitively and contains a pure package from Allah SWT (tauqifi), that is why the verses of the Qur'an that explain about inheritance are not many, only three places regulate in detail, detail, and clear. Even so al-Qur'an still provides ijtihâd space in understanding the Qur'anic texts related to the explanation of inheritance law.

KHI article 192 " Apabila dalam pembagian warisan di antara para ahli warisnya Dzawil furud menunjukkan bahwa angka pembilang lebih besar dari angka penyebut, maka 
angka penyebut dinaikkan sesuai dengan pembilang, dan baru sesudah itu harta warisnya dibagi secara aul menurut angka pembilang ".

The heirs in KHI article 192 are heirs only consisting of Drawil furud, the heirs who receive a definite share. The portion received by Drawil furud is a definite part, namely: 1 / 2,14.1 / 8, and 2/3,1 / 3.1 / 6), the part must be given by Drawil furud in full, meaning that it should not be added let alone reduced, but the other side of inheritance is not sufficient to be given to the heirs in full, therefore, done in Aul.

The Aul case in article $192 \mathrm{KHI}$ only applies to the heirs of Drawil furud, the heirs who received the definite portion that has been explained by Allah. in the Qur'an definitively In Aul's case the gains of each of Dzawil furud were reduced and decreased according to their share, even though the reduction was different but the fact of the reduction was the same. Because both are reduced and the same reduction is still a fair category.

The Aul case in article $192 \mathrm{KHI}$ was included in the domain of figh so that it was included in the category of ijtihad problems but there was still a chance of a difference

Keyword: legacy, KHI, Islamic law

\section{PENDAHULUAN}

Kewarisan Islam, Ilmu Farâiidh atau waris Islam adalah membahas atau mengatur tentang berbagai macam hal dalam pembagian harta peninggalan kepada yang berhak menerimanya atas dasar ketentuan yang telah ditetapakan dalam al-Qur'an, sunnah Nabi saw. dan kesepakatan ulamâ'. Pembuat ilmu farầidh atau waris Islam adalah Allah swt. Obyeknya adalah pembagian harta peninggalan kepada ahli waris yang berhak menerima. Faedahnya dengan ilmu tersebut, dapat memberikan hak ahli waris atas harta peninggalan (HP) sesuai dengan tuntunan syariat Islam berdasarkan Al-Qur'an, Al- $\underline{H}$ adîts, Al-'Ijmấ dan Al-Qiyâs. Waris dalam Islam memuat aturan hukum mengenai perpindahan harta milik mayat secara definitif dan bermuatan paket murni dari Allah SWT (tanqifi), itulah sebabnya ayat-ayat al-Qur'an yang menjelaskan tetntang waris tidak banyak, hanya tiga tempat saja yang mengatur secara rinci,

\footnotetext{
${ }^{1}$ Muhammad al-Zuhaili, al-Farâ'idh wa alMawârits wa al-washâya, Cet ke-1 (Bairut : Dar alQalam at-Thayyib, 2001), 55. 
detail, dan jelas. Sekalipun demikian al-Qur'an tetap memberikan ruang ijtihâd dalam memahami nash al-Qur'an yang berkaitan dengan penjelasan tetang pembagihan harta peninggalan atau hukum kewarisan.

\section{AYAT-AYAT HUKUM KEWARISAN}

1. Surat An-Nisâ' ayat 11.

Menjelasan bagian anak laki-laki dan anak perempuan (walad)

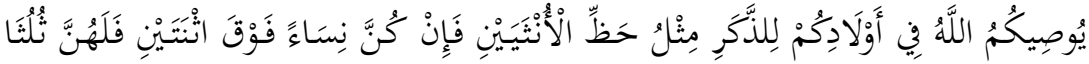

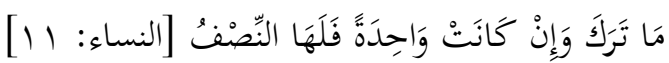
"Allah mensyariatkan bagimu tentang (pembagian pusaka untuk) anakanakmu. Yaitu bahagian seorang anak lelaki sama dengan bahagian dua orang anak perempuan. Jika anak itu semuanya perempuan lebih dari dua, maka bagi mereka dua pertiga dari harta yang ditinggalkan. Jika anak perempuan itu seorang saja, maka ia memperoleh setengah harta. (Q.S. AnNisâ: 11). ${ }^{2}$

Shahabat Zaid bin Tsâbit r.a. berkata, apabila laki-laki atau perempuan meninggal dan meninggalkan seorang anak perempuan maka bagiannya $1 / 2$ dan jika meninggalkan dua orang anak atau lebih bagian mereka 2/3. ${ }^{3}$ Cucu laki-laki dari anak laki-laki disamakan dengan anak lakilaki, jika mayat tidak meninggalkan anak laki-laki. Dan cucu perempuan dari anak laki-laki disamakan dengan anak perempuan, jika mayat tidak meninggalkan anak perempuan. Sebab kata walad mencakup anak, cucu, dan cicit. Sebagaimana kesepakatan 'ulamâ' fiqih.

Bagian orang tua (Bapak-Ibu).

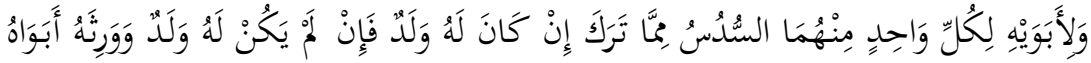

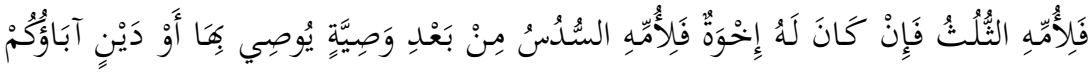

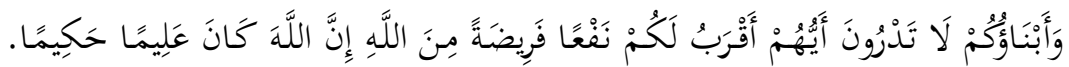

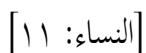

Dan untuk dua orang ibu bapak, bagi masing-masing seperenam dari harta yang ditinggalkan, jika yang meninggal itu mempunyai anak, jika orang yang meninggal tidak mempunyai anak dan ia diwarisi oleh ibu-bapaknya (saja), maka ibunya mendapat sepertiga, jika yang meninggal itu mempunyai

\footnotetext{
${ }^{2}$ Departemen Agama Republik Indonesia, al-Qur'an dan Terjemabnya (Jakarta : Yayasan Penyelenggara Penterjemah/Pentafsir al-Qur'an, 1971), 116

3 al-Bukhâri, Abi Abdillah M. bin Ismâ'il mtn shahih al-Bukhâri,(singapura, t.th) 165
} 
beberapa saudara, maka ibunya mendapat seperenam, (pembagian-pembagian tersebut di atas) sesudah dipenubi wasiat yang ia buat atau (dan) sesudah dibayar hutangnya. (Tentang) orang tuamu dan anak-anakmu, kamu tidak mengetabui siapa di antara mereka yang lebih dekat (banyak) manfa'atnya bagimu. Ini adalah ketetapan dari Allah. Sesunggubnya Allab Maba Mengetabui lagi Maha Bijaksana. (Q.S. An-Nisâ': 11). ${ }^{4}$

2. Surat An-Nisâ' ayat 12 .

Menjelaskan bagian suami/duda.

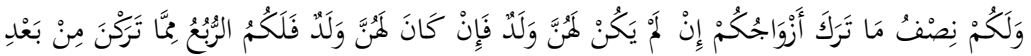

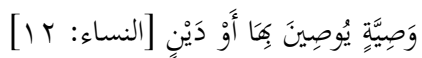

Dan bagimu (suami-suami) seperdua dari harta yang ditinggalkan oleh istriistri mu, jika mereka tidak mempunyai anak, jika istri-istrimu itu mempunyai anak, maka kamu mendapat seperempat dari harta yang ditinggalkannya sesudah dipenubi wasiat yang mereka buat atau (dan) sesudah dibayar hutangnya. (Q.S. An-Nisâ': 12). ${ }^{5}$

Bagian janda atau beberapa janda.

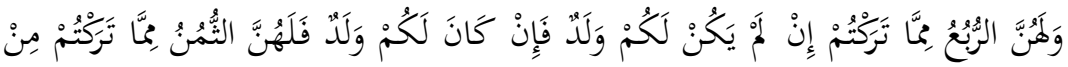

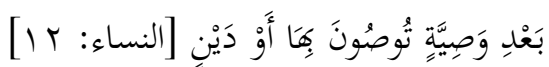

Para istri memperoleh seperempat dari harta yang kamu tinggalkan, jika kamu tidak mempunyai anak, jika kamu mempunyai anak, maka para istri mendapat seperdelapan dari harta yang kamu tinggalkan sesudab dipenubi wasiat yang kamu buat atau (dan) sesudah dibayar butang-butangmu. (Q.S. An-Nisâ': 12). ${ }^{6}$

Bagian saudara seibu (laki-laki dan perempuan).

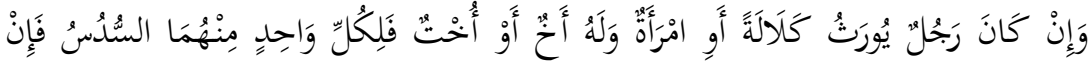

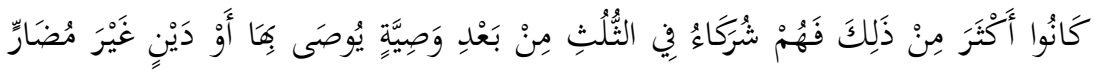

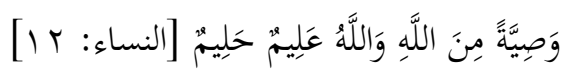

"Tika seorang mati, baik laki-laki maupun perempuan yang tidak meninggalkan ayah dan tidak meninggalkan anak, tetapi mempunyai seorang saudara laki-laki (seibu saja) atau seorang saudara perempuan (seibu saja) maka bagi masing-masing dari kedua jenis saudara itu seperenam harta.

\footnotetext{
${ }^{4}$ Departemwn agama, Al-Qur'an, 117.

${ }^{5}$ Ibid.,

${ }^{6}$ Ibid.,

96 Syuhada' - Penerapan pembagian harta warisam
} 
Tetapi jika saudara-sandara seibu itu lebih dari seorang, maka mereka bersekutu dalam yang sepertiga itu, sesudab dipenubi wasiat yang dibuat olehnya dengan tidak memberi mudharat (kepada abli waris). (Allah menetapkan yang demikian itu sebagai) sebagai syari'at yang benar-benar dari Allah, dan Allah Maha Mengetabui lagi Maha Penyantun. (Q.S. AnNisâ': 12). ${ }^{7}$

3. Surat An-Nisâ' ayat 176 .

Menjelaskan bagian saudara sekandung (laki-laki dan perempuan)

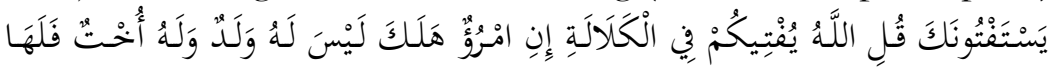

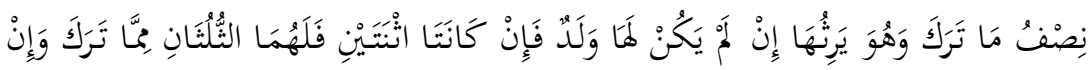

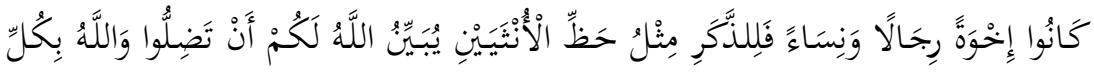
شَيْيٍ عَلِيمُ [النساء:

Mereka mintak fatwa kepadamu tentang (kalâlah). Katakanlah "Allah memberi fatwa kepadamu tentang kalala (yaitu): Jika seorang meninggal dunia, dan ia tidak mempunyai anak dan mempunyai saudara perempuan, maka bagi saudaranya yang perempuan itu seperdua dari harta yang ditinggalkannya, dan saudaranya yang laki-laki mempusakai (selurub harta saudara perempuan), jika ia tidak mempunyai anak; tetapi jika saudara perempuan itu dua orang, maka bagi keduanya dua pertiga dari barta yang ditinggalkan oleh yang meninggal. Dan jika mereka (abli waris itu terdiri dari) saudara-saudara laki-laki dan perempuan, maka bagian seorang saudara laki-laki sebanyak bahagian dua orang saudara perempuan. Allah menerangkan (bukum ini) kepadamu, supaya kamu tidak sesat. Dan Allah Maha Mengetahui segala sesuatu. (Q.S. An-Nisâ’: 176). ${ }^{8}$

\section{HADITS-HADITS MAWARITS}

1. Tata-tata cara membagi warisan. Penerima bagian pasti didahulukan setelah itu baru 'ashabah

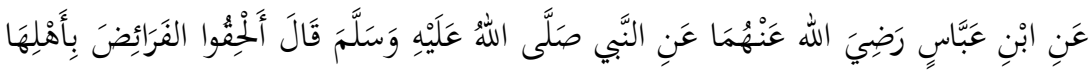

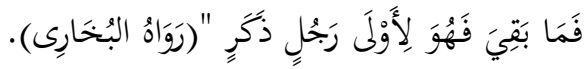

\footnotetext{
${ }^{7}$ Ibid.,

${ }^{8}$ Ibid., 153
} 
Dari Ibnu Abbas ra. dari Nabi saw. "Nabi saw bersabda: Berikanlab bagian-bagian pasti kepada abli waris yang berbak. Sesudab itu sisanya diutamakan (untuk) orang laki-laki ('asabah)". (HR. al-Bukbâri).'

2. Orang muslim tidak diperbolehkan mewaris harta peninggalan orang kafir dan sebaliknya.

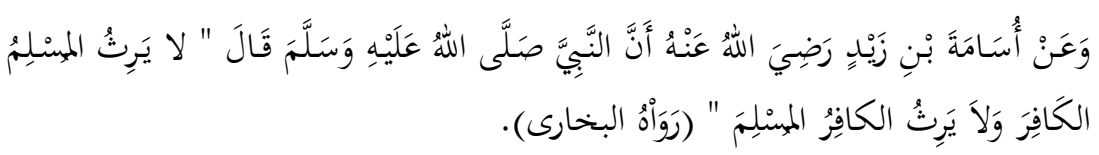

Dari 'Usâmah bin Zaid r.a. Rasulullah saw. bersabda "Orang muslim tidak berbak mewarisi orang kafir, dan orang kafir tidak berbak mewarisi orang muslim". (HR. Imam Bukhâri)

3. Cucu perempuan mendapat bagian $1 / 6$ untuk melengkapi bagian $1 / 2$ yang diterima anak perempuan sehingga bagian anak perempuan dan cucu perempuan menjadi 2/3. Dan saudara perempuan sekandung sebagai 'ashabah ma' al ghair jika bersama dengan anak perempuan atau cucu perempuan.

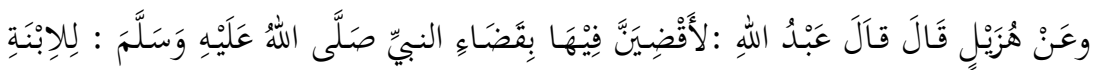

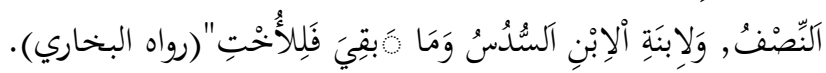

Dari Huzail berkata, Abdullah berkata, saya pasti akan menghukumi masalah (pembagaian harta peninggalan) sebagaimana Nabi saw. menghukumi, untuk bagian anak perempuan setengah (1/2) sedangkan bagiannya сиси perempuan adalah seperenam, lalu sisanya diberikan pada saudara perempuan (sekandung/seayah). (HR. Imam Bukhâri). ${ }^{11}$

4. Maksimal wasiat dan radd

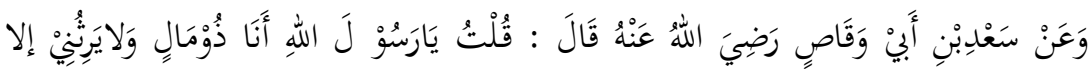

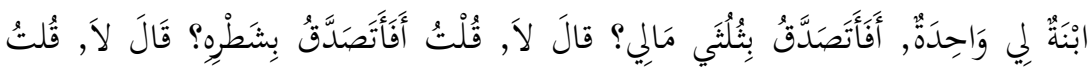

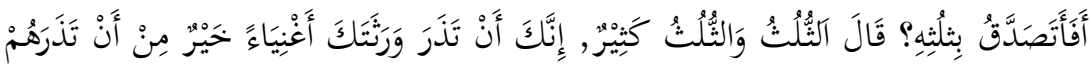

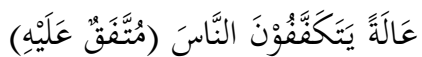

"Dari Sa'ad bin Abi Waqâsh ra. berkata aku berkata wahai Rasul Aku adalah orang kaya dan tidak mempunyai abli waris kecuali seorang anak perempuan, bolebkah aku bersedekah dengan dua pertiga hartaku? Rasul

\footnotetext{
${ }^{9}$ Al-Bukhâri, Shahîh Al-Bukhâri. 165

${ }^{10}$ Ibid., 170

${ }^{11}$ Ibid., 167

98 Syuhada' - Penerapan pembagian harta warisam
} 
menjawab: jangan. Aku berkata: separubnya? Rasul menjawab: jangan. Aku berkata: sepertiga? Rasul menjawab: sepertiga sudab banyak. Sesunggubnya bagimu akan lebih baik meninggalkan pewarismu kaya dari pada meninggalkan mereka dalam keadaan miskin dan meminta belas kasiban kepada orang lain. (HR.Bukhâri Muslim). ${ }^{12}$

5. Hukum Mempelajari dan Mengajar Ilmu Farâ’idh

Hukum mempelajari dan mengajar ilmu farâidh adalah fardhu'ain yaitu kewajiban yang harus dilakukan oleh setiap individu. Berdasarkan redaksi hadîts yang menggunakan bentuk perintah ('amar) yaitu hadîts yang diriwatkan oleh Ibn Mas'ûd ra.:

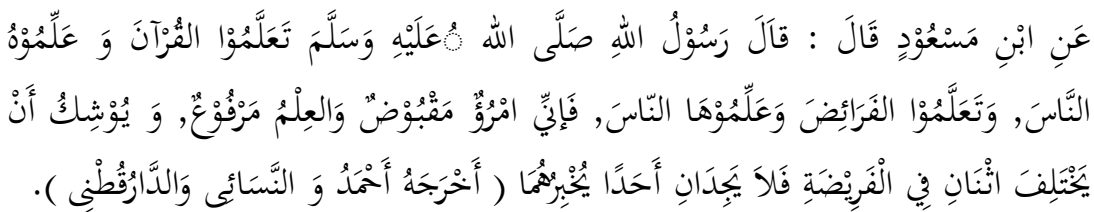

Dari ibnu Mas'ûd berkata, Rasulullah saw. bersabda: "Pelajarilab oleh kalian Al-Qur'an dan ajarkanlah kepada orang lain, dan pelajarilah ilmu farâ'idh dan ajarkanlab kepada orang lain, karena sesunggubnya aku adalah orang yang bakal terenggut (meninggal), sedangkan ilmu faraidl akan bilang. Hampir saja dua orang yang berselisih tentang pembagian harta warisan tidak menjumpai seorang pun yang dapat memberikan fatwa kepada mereka berdua" (HR. Ahmad, An-Nasẩi dan Ad-Dâr qutni). ${ }^{13}$

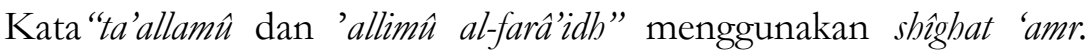
Dalam kaidah ushul fiqib bentuk 'amr pada yang diperintah adalah wajib. Dan juga dapat berhukum fardh kifâyah, yaitu kuwajiban yang dibebankan atas semua mukallaf. Namun, tolak ukurnya ada pada target capaian, bukan pada respon individu. Bila target beban sudah tercapai, dalam arti sudah dikerjakan oleh seseorang dari kelompok mereka, maka sebagian orang yang termasuk kelompok mereka dianggap cukup (kifâyah).

Al-Qur'an merupakan acuan pertama hukum dan penentuan pembagian waris. Bahkan tidak ada ketentuan hukum lain yang sebegitu baku dalam al-Qur'an seperti halnya dalam persoalan hukum waris. Hanya saja, dalam teks al-Qur'an ketentuan waris sangat terbatas dan global sekali, peran hadits disampng sebagai bayân Al-Qur'an juga ikut menetapkan aturan dan juga menjelaskan tentang tata cara membagi harta peninggalan (HP). Meski demikian ruang ijtihâd tetap terbuka untuk pembagian harta peninggalan (HP), apalagi munculnya kasus-kasus pasca

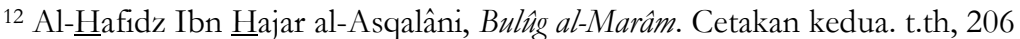

13 Asy-Syaukani, Nail al-'Authâr, juz 6, (Bairut ; Dar al-Fikr, t.th) 168.
} 
wafatnya baginda Rasulullah SAW, seperti kasus Gharrawain, Musytarakah, Akdariyyah, Aul dan Radd, dll.

Islam memandang harta adalah milik Allah SWT semata, sedangkan manusia ditunjuk sebagai penguasanya. Begitu orang yang diamanati dan yang dititipi itu meninggal dunia, maka, harta kembali menjadi milik Allah swt secara otomatis. Oleh karena itu Allah swt. berhak ikut mengatur harta yang ditinggalkan oleh pemiliknya, paling tidak dengan sifat rabmân kepada mablúq-Nya Allah swt mewakili mayat sebagai pemilik yang sudah tidak berdaya. Aturan yang ditetapkan oleh Allah swt adalah diberikan kepada keluarga yang ditunjuk dengan aturan wahyu. Dalam Fiqh Islam dikenal empat sebab milik yaitu; al-'aqd (transaksi), tawallud min al-milk (perkembangan harta milik) dan ihrâz al-mubahat (eksplorasi kepemilikan umum), dan al-khalafiyah/irtsun (penerus kepemilikan atau warisan). Zakariya al-Anshari menyebut ada sebab umum dan ada pula sebab khusus dalam hal mendapatkan harta secara halâl dari sisi khalafiyah (penerusan kepemilikan) dengan media pewarisan. Sebab umum dimana seseorang berhak mendapat warisan adalah beragama Islam. ${ }^{14}$ Sedangkan sebab khusus cara mendapatkan harta secara halâl dalam khalafiyah (penerusan kepemilikan) dengan media pewarisan adalah :

a. Hubungan kerabat khusus, yang mempunyai hubungan darah dengan mayat.

b. Melangsungkan akad pernikahan secara sah menurut syari'at Islam

c. waris walá' atau mendapatkan warisan karena memerdekakan budak, disebut juga dengan nasab bukmi, ${ }^{15}$

\section{KHI pasal 176}

KHI pasal 192 "Apabila dalam pembagian warisan di antara para ahli warisnya Dzawil furud menunjukkan bahwa angka pembilang lebih besar dari angka penyebut, maka angka penyebut dinaikkan sesuai dengan pembilang, dan baru sesudah itu harta warisnya dibagi secara aul menurut angka pembilang".

Ahli waris dalam KHI pasal 192 adalah ahli waris hanya terdiri dari Dwawil furud yaitu ahli waris penerima bagian pasti. Bagian yang diterima oleh Dwawil furud adalah bagian pasti, yaitu : 1/2,14,1/8, dan $2 / 3,1 / 3,1 / 6)$, bagian tersebut wajib diberikan oleh Dwawil furud secara penuh, artinya tidak boleh ditambah apalagi mengurangi, tetapi sisi yang lain harta warisan tidak mencukupi untuk diberikan kepada ahli waris secara penuh, oleh sebab itu, dilakukan secara aul.

14 Zakariya al-Ansari, Sharh al-Tahrir. (Surabaya: Maktabat Salim b. Sa'ad b. Nabhan, t.th), 86-87.

${ }^{15}$ Ahmad 'Abd al-Jawad, Ushul Tlm al-Mawarith, Cet. II, (Beirut : Da>r al-Jil, 1986), 1-2. 


\section{Pengertian Dwawil Furud dan Bagian Mereka}

Dwawil Furud adalah ahli waris yang mendapatkan bagian pasti.

\begin{tabular}{|c|c|c|c|}
\hline \multicolumn{3}{|c|}{ Dwawil Furud adalah : } & Bagian pasti \\
\hline 1 & الزَّْْجُ & Suami (duda) & $1 / 2,1 / 4$ \\
\hline 2 & 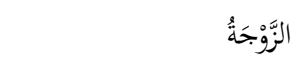 & Istri (janda) & $1 / 4,1 / 8$ \\
\hline 3 & البِنْتُ & Anak perempuan & $1 / 2,2 / 3$ \\
\hline 4 & بنْتُ الإِبْنِ وَإِنْ نَزَزلَ أبوُهَا & Cucu perempuan & $1 / 2,2 / 3,1 / 6$ \\
\hline 5 & الأَبُ & Bapak & $1 / 6,1 / 6+$ Sisa \\
\hline 6 & 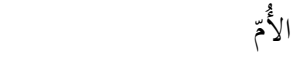 & Ibu & $1 / 3,1 / 6,1 / 3$ Sisa \\
\hline 7 & الجحدّ (أبُ الأبِ) وَإِنْ عَلا & Kakek & $1 / 6,1 / 6+$ Sisa \\
\hline 8 & 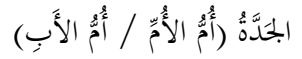 & Nenek & $1 / 6$ \\
\hline 9 & الأُخْتِتُ الشَقَيْيَعَة & Sdr. pr. kandung. & $1 / 2,2 / 3$ \\
\hline 10 & الأُخْتُ لِلأَبِ & Sdr. pr. Seayah & $1 / 2,2 / 3,1 / 6$ \\
\hline 11 & 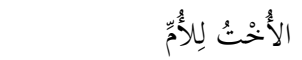 & Sdr. pr. Seibu & $1 / 3,1 / 6$ \\
\hline 12 & الأَخُْ لِلأُعْ & Sdr. lk. Seibu & $1 / 3,1 / 6$ \\
\hline
\end{tabular}

\section{PEMBAHASAN Al-‘Aul (آَلْعَلُ)}

\section{Pengertian}

'Aul adalah bagian pasti dalam pembagian warisan lebih besar dari pada harta peninggalan/Asal Masalah (AM) dan berdampak pada bagian yang diterima oleh masing-masing Drawil furud berkurang sesuai bagian mereka. ${ }^{16}$ berikut :

Misalkan dalam pembagian warisan ada bagian pasti sebagai

$$
-1 / 2,1 / 2, \text { dan } 1 / 6
$$$$
-1 / 2,1 / 2,1 / 6, \operatorname{dan}^{1} / 6
$$$$
-1 / 2,2 / 3, \text { dan }^{1} / 6
$$

Masing-masing bagian pasti tidak mungkin dapat dipenuhi karena harta tidak cukup dan tidak juga mendahulukan salah satu dari bagian mereka, karena dapat mengurangai bagian ahli waris yang lain. Oleh

\footnotetext{
16 Muhammad al-Zuhaili, al-Farâ'idl wa al-Mawârits wa al-Washâyâ, Cet. 1 (Bairut : Dâr alQalam, 2001), 238.
} 
karena itu, bagian semua ahli waris dikurangi sesuai bagian mereka, supaya harta peninggalan dapat dibagi.

Kasus 'Aul ini, terjadi pada masa khalifah shahabat Umar bin Khaththâb r.a. ada seorang wafat, sedangkan ahli warisnya: suami dan dua saudara perempuan sekandung. Suami mendapat bagian $1 / 2$ dan dua saudara perempuan $2 / 3$. Bagian $1 / 2$ dan $2 / 3$ lebih besar dari pada harta warisan. Suami dan dua saudara perempuan menuntut bagian secara penuh. Shahabat Umar bin Khaththâb r.a. Menjawab saya tidak tahu siapa yang didahulukan dan diakhirkan. Jika suami didahulukan, maka dua saudara terkurangi dan sebaliknya. Orang pertama melakukan 'Aul, Shahabat 'Abbâs r.a., Ali bin Abi Thâlib r.a., atau Zaid bin Tsâbit r.a. ${ }^{17}$

\section{Cara Penyelesaian}

Penyelesaian kasus 'Aul adalah 'Jumlah bagian yang diterima oleh ahli waris menjadi Asal Masalah (AM)". Dan AM sebelum penerapan teori Aul tidak dipakai.

\begin{tabular}{|c|c|c|c|}
\hline \multirow{2}{*}{\multicolumn{2}{|c|}{ Ahli waris }} & \multicolumn{2}{|c|}{ Aul (AM:6+1=7) } \\
\hline & & \multicolumn{2}{|c|}{ AM : 6} \\
\hline 1 & زَوْجُج & $1 / 2$ & 3 bagian \\
\hline 2 & 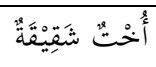 & $1 / 2$ & 3 bagian \\
\hline 3 & أُ أُخْتُ لِأَبٍ & $1 / 6$ & 1 bagian \\
\hline \multicolumn{3}{|c|}{ Jumlah } & 7 bagian \\
\hline
\end{tabular}

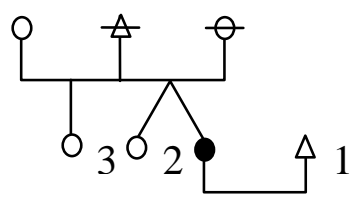

\section{Penjelasan :}

AM 6. Suami mendapat 3 bagian, saudara perempuan sekandung juga mendapat 3 bagian, dan saudara perempuan seayah mendapat 1 bagian. Jumlah yang diterima oleh ahli waris adalah 7 bagian menjadi AM. Dan AM sebelumnya yaitu 6 tidak dipakai. Dengan mengganti AM 7, otomatis bagian ahli waris turun atau berkurang dan turunnya atau berkurangnya sesuai bagian mereka.

\section{Keterangan :}

$\checkmark \triangle$ Ahli waris lk $\bigcirc$ ahli waris pr.

$\checkmark \triangle \bigcirc$ 2. Ahli waris wafat sebelum mayat

Misalkan harta peninggalan (HP) itu adalah Rp 42.000.000 maka, pembagian sebelum dan sesudah teori 'aul diterapkan adalah sbb. :

\footnotetext{
${ }^{17}$ Musthafa, ar-Rahabiyyah Ilmu Farâ'idh, (Damsik : Dâr al-Qalam, 2004), 113. 
a. Sebelum teori' $a u l: \frac{H P: R p 42.000 .000}{A M: 6}=R p 7.000 .000$

\begin{tabular}{|c|c|c|c|c|}
\hline \multicolumn{2}{|c|}{ Ahli waris } & \multicolumn{2}{|c|}{ Bagian yang seharusnya diterima } & Keterangan \\
\hline 1 & زَوْجُجْ & $3 \times \operatorname{Rp} 7.000 .000$ & Rp 21.000.000 & Bagian pasti \\
\hline 2 & أُخْنْتُ شَقَقِيْقَةُ & $3 \times \operatorname{Rp} 7.000 .000$ & Rp 21.000.000 & Bagian pasti \\
\hline 3 & أُجْتَتُ لِأَبٍ & $1 \times \operatorname{Rp} 7.000 .000$ & Rp 7.000 .000 & Bagian pasti \\
\hline \multicolumn{3}{|c|}{ Jumlah } & Rp 49.000.000 & \\
\hline
\end{tabular}

\section{Penjelasan :}

Suami mendapat Rp 21.000.000, saudara perempuan sekandung mendapat $\mathrm{Rp} 21.000 .000$, saudara perempuan seayah mendapat $\mathrm{Rp}$ 7.000.000. Jumlahnya Rp 49.000.000, tidak mungkin membagi seperti ini, yang nomboi sopo. Padahal mereka menerima warisan sesuai dengan bagian mereka.

b. Sesudah teori 'aul: $\frac{H P: R p 42.000 .000}{A M: 7}=R p 6.000 .000$

\begin{tabular}{|c|c|c|c|c|}
\hline \multicolumn{2}{|c|}{ Ahli waris } & \multicolumn{2}{|c|}{ Ternyata bagian yang diterima } & \multirow{2}{*}{$\begin{array}{r}\text { Berkurang } \\
\text { Rp } 3.000 .000\end{array}$} \\
\hline 1 & زَوْجُج & $3 x \operatorname{Rp} 6.000 .000$ & Rp 18.000 .000 & \\
\hline 2 & 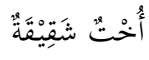 & $3 x \operatorname{Rp} 6.000 .000$ & Rp 18.000 .000 & Rp 3.000 .000 \\
\hline 3 & أُخْتِتُ للَأَبٍ & $1 \times R p 6.000 .000$ & $\operatorname{Rp} 6.000 .000$ & Rp 1.000 .000 \\
\hline \multicolumn{3}{|c|}{ Jumlah } & Rp 42.000.000 & \\
\hline
\end{tabular}

\section{Penjelasan :}

Suami mendapat bagian Rp 18.000.000, saudara perempuan sekandung mendapat bagian Rp 18.000.000, saudara perempuan seayah mendapat bagian Rp 6.000.000. Jumlahnya yang diterima oleh semua ahli waris Rp 42.000.000. sesuai harta peninggalan mayat. Bagian ahli waris setip Rp 7.000.000 turun Rp 1.000.000 dan turunnya sama, ini maksud kasus 'Aul.

CATATAN :

1. $\mathrm{AM}=$ Asal Masalah 
2. $\mathrm{HP}=$ Harta peninggalan Mayat

\section{Asal Masalah yang Menerima Kasus Aul}

Asal Masalah yang disepakati oleh Fuqaha' ada tiga macam; (a). 2, 4, dan 8. (b). 3 dan 6. (c). 12 dan 24. Tidak semuanya asal masalah (AM) di atas, dapat menerima kasus Aul. Asal Masalah (AM) yang dapat menerima kasus ' $A u l$ adalah : 6, 12, dan 24 dengan rincian, contoh, dan penjelasan sbb.:

\section{Asal Masalah 6}

AM 6 dapat di 'Aukan (naik) sampai 10 katagorinya bilangan genap dan bilangan ganjil. Uraiannya :

1. $\mathrm{AM} 6+1=7$

\begin{tabular}{|c|c|c|c|}
\hline \multirow{2}{*}{\multicolumn{2}{|c|}{ Ahli waris }} & \multirow{2}{*}{\multicolumn{2}{|c|}{$\begin{array}{c}\text { Aul: }(\mathrm{AM}: 6+1=7) \\
\mathrm{AM}: 6\end{array}$}} \\
\hline & & & \\
\hline 1 & زَزْوجُ & $1 / 2$ & 3 baøian \\
\hline 2 & 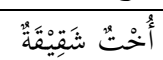 & $1 / 2$ & 3 bagian \\
\hline 3 & 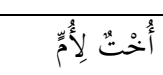 & $1 / 6$ & 1 pagian \\
\hline \multicolumn{3}{|c|}{ Jumlah } & 7 bagian \\
\hline
\end{tabular}

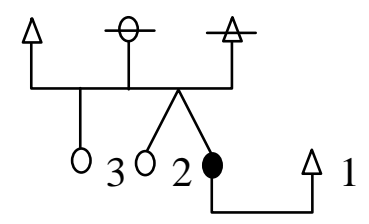

Misalkan HP. Rp 42.000.000 pembagian sebelum dan sesudah teori ' $A u l$ :

a) Sebelum teori 'aul: $\frac{H P: R p 42.000 .000}{A M \cdot 6}=R p 7.000 .000$

\begin{tabular}{|c|c|c|c|}
\hline Ahli waris & \multicolumn{2}{|c|}{ Bagian yang seharusnya diterima } & Keterangan \\
\hline زَوْجْ & $3 \times \operatorname{Rp} 7.000 .000$ & Rp 21.000.000 & Bagian pasti \\
\hline أُخْنت شَقِقِيْقَةُ & $3 \times \operatorname{Rp} 7.000 .000$ & Rp 21.000 .000 & Bagian pasti \\
\hline 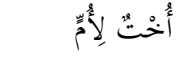 & $1 \times \operatorname{Rp} 7.000 .000$ & Rp 7.000 .000 & Bagian pasti \\
\hline \multicolumn{2}{|c|}{ Jumlah } & $\mathrm{Rp} 49.000 .000$ & \\
\hline
\end{tabular}

b) Sesudah teori 'aul: $\frac{H P: R p 42.000 .000}{A M: 7}=R p 6.000 .000$

\begin{tabular}{|c|c|c|c|}
\hline Ahli waris & \multicolumn{2}{|c|}{ Ternyata bagian yang diterima } & Berkurang \\
\hline زَوْجِج & $3 \times R p 6.000 .000$ & Rp 18.000.000 & Rp 3.000.000 \\
\hline
\end{tabular}




\begin{tabular}{|c|c|c|c|}
\hline أُخْختُ شَقِقِيَقَةُ & $3 \times \operatorname{Rp} 6.000 .000$ & Rp 18.000.000 & Rp 3.000.000 \\
\hline 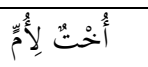 & 1xRp 6.000 .000 & Rp 6.000 .000 & Rp 1.000.000 \\
\hline \multicolumn{2}{|c|}{ Jumlah } & Rp 42.000 .000 & \\
\hline
\end{tabular}

2. $\mathrm{AM}: 6+2=8$

\begin{tabular}{|c|c|c|c|}
\hline Ahli waris & \multicolumn{3}{|c|}{$\operatorname{Aul}(\mathrm{AM}: 6+2=8)$} \\
\hline & \multicolumn{2}{|c|}{$\mathrm{AM}: 6$} & 4 \\
\hline 1 & زَوْجَج & $1 / 2$ & 3 bagian \\
\hline 2 & أُمْنِ & $1 / 6$ & 1 bagian \\
\hline 3 & أُخْنتُ شَقِمِيَعَةُ & $1 / 2$ & 3 bagian \\
\hline 4 & أُخْتَتُ لِأَبٍ & $1 / 6$ & bagian \\
\hline \multicolumn{3}{|c|}{ Jumlah } & 8 bagian \\
\hline
\end{tabular}

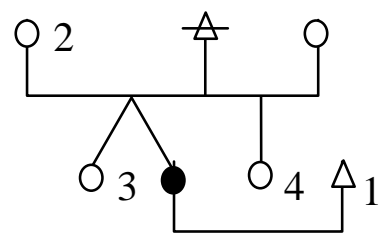

\section{Penjelasan}

Jumlah bagian yang diterima ahli waris adalah 8, ditetapkan sebagai AM dan AM sebelumnya 6 tidak dipakai. Dengan mengganti AM otomatis bagian yang diterima oleh ahli waris berkurang sesuai bagian mereka.

Misalkan HP. Rp 48.000.000 pembagian sebelum dan sesudah teori 'Aul:

a) Sebelum teori ' $a u l: \frac{H P: R p 48.000 .000}{A M: 6}=R p 8.000 .000$

\begin{tabular}{|c|c|c|c|c|}
\hline \multicolumn{2}{|c|}{ Ahli waris } & \multicolumn{2}{|c|}{ Bagian yang seharusnya diterima } & Keterangan \\
\hline 1 & زَوْجُج & $3 \times \operatorname{Rp} 8.000 .000$ & Rp 24.000.000 & Bagian pasti \\
\hline 2 & أَمْمِ & $1 \times \operatorname{Rp} 8.000 .000$ & Rp 8.000 .000 & Bagian pasti \\
\hline 3 & أُخْْتِ شَقَِيْقَةُ & $3 \times \operatorname{Rp} 8.000 .000$ & Rp 24.000.000 & Bagian pasti \\
\hline 4 & أُخْنْتُ لِأَبٍ & $1 \times \operatorname{Rp} 8.000 .000$ & Rp 8.000.000 & Bagian pasti \\
\hline \multicolumn{3}{|c|}{ Jumlah } & Rp 64.000 .000 & \\
\hline
\end{tabular}

b) Sesudah teori 'aul: $\frac{H P: R p 48.000 .000}{A M: 8}=R p 6.000 .000$

\begin{tabular}{|c|c|c|c|c|}
\hline \multicolumn{2}{|c|}{ Ahli waris } & \multicolumn{2}{|c|}{ Ternyata bagian yang diterima } & Berkurang \\
\hline 1 & زَوْجُج & $3 \times \operatorname{Rp} 6.000 .000$ & Rp 18.000.000 & $\operatorname{Rp} 6.000 .000$ \\
\hline
\end{tabular}




\begin{tabular}{|c|c|c|c|c|}
\hline 2 & أُمْ مُ & $1 \times \operatorname{Rp} 6.000 .000$ & $\operatorname{Rp} 6.000 .000$ & Rp 2.000.000 \\
\hline 3 & 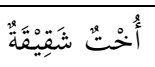 & $3 \times \operatorname{Rp} 6.000 .000$ & Rp 18.000.000 & Rp 6.000 .000 \\
\hline 4 & أُخْنَتُ لِأَبٍ & $1 \times \operatorname{Rp} 6.000 .000$ & Rp 6.000 .000 & Rp 2.000.000 \\
\hline \multicolumn{3}{|c|}{ Jumlah } & $\mathrm{Rp} 48.000 .000$ & \\
\hline
\end{tabular}

3. $\mathrm{AM}: 6+3=9$

\begin{tabular}{|c|c|c|c|}
\hline \multirow{2}{*}{\multicolumn{2}{|c|}{ Ahli waris }} & \multicolumn{2}{|c|}{$\operatorname{Aul}(\mathrm{AM}: 6+3=9)$} \\
\hline & & \multicolumn{2}{|c|}{$\mathrm{AM}: 6$} \\
\hline 1 & زَوْجْج & $1 / 2$ & 3 baqfian \\
\hline 2 & أُ & $1 / 6$ & 1 bagian \\
\hline 3 & 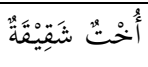 & $1 / 2$ & 3 bagian \\
\hline 4 & أُخْتْتُ لِأًَب & $1 / 6$ & 1 pagian \\
\hline 5 & 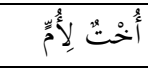 & $1 / 6$ & $1 /$ bagian \\
\hline \multicolumn{3}{|c|}{ Jumlah } & 9 bagian \\
\hline
\end{tabular}

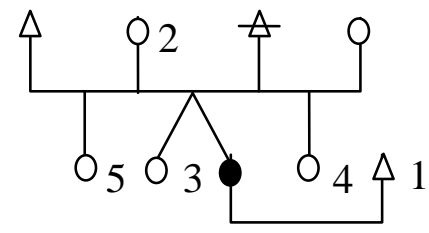

\section{Penjelasan}

Jumlah bagian yang diterima ahli waris adalah 9, menjadi AM. dan AM sebelumnya adalah 6 tidak dipakai. Dengan mengganti AM, maka bagian ahli waris berkurang sesuai bagian mereka.

Misalkan HP. Rp 54.000.000 pembagian sebelum dan sesudah teori 'Aul:

a) Sebelum teori ' $a u l: \frac{H P: R p 54.000 .000}{A M: 6}=R p 9.000 .000$

\begin{tabular}{|c|c|c|c|c|}
\hline \multicolumn{2}{|c|}{ Ahli waris } & \multicolumn{2}{|c|}{ Bagian yang seharusnya diterima } & Ket. \\
\hline 1 & زَوْجْج & $3 \times \operatorname{Rp} 9.000 .000$ & Rp 27.000.000 & Bagian pasti \\
\hline 2 & 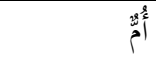 & $1 \times R p 9.000 .000$ & Rp 9.000 .000 & Bagian pasti \\
\hline 3 & أُخْنت شَقِقِيْقَةُ & $3 \times \operatorname{Rp} 9.000 .000$ & Rp 27.000.000 & Bagian pasti \\
\hline 4 & أُخْنَتُ لِأَبٍ & $1 \times R p 9.000 .000$ & Rp 9.000 .000 & Bagian pasti \\
\hline 5 & 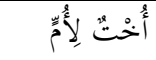 & $1 \times R p 9.000 .000$ & $\mathrm{Rp} 9.000 .000$ & Bagian pasti \\
\hline
\end{tabular}

b) Sesudah teori 'aul: $\frac{H P: R p 54.000 .000}{A M: 9}=R p 6.000 .000$

\begin{tabular}{|c|c|c|c|c|}
\hline \multicolumn{2}{|c|}{ Ahli waris } & \multicolumn{2}{|c|}{ Ternyata bagian yang diterima } & Berkurang \\
\hline 1 & زَوْْجُ & $3 \times \operatorname{Rp} 6.000 .000$ & Rp 18.000 .000 & Rp 9.000 .000 \\
\hline 2 & 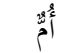 & $1 \times \operatorname{Rp} 6.000 .000$ & $\mathrm{Rp} 6.000 .000$ & Rp 3.000 .000 \\
\hline
\end{tabular}

106 Syuhada' - Penerapan pembagian harta warisam 


\begin{tabular}{|c|c|c|c|c|}
\hline 3 & 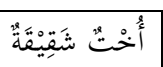 & $3 \times \operatorname{Rp} 6.000 .000$ & Rp 18.000.000 & Rp 9.000 .000 \\
\hline 4 & أُخْنتُ لِأَبِ & $1 \times \operatorname{Rp} 6.000 .000$ & $\operatorname{Rp} 6.000 .000$ & Rp 3.000 .000 \\
\hline 5 & 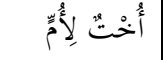 & $1 \times \operatorname{Rp} 6.000 .000$ & Rp 6.000 .000 & Rp 3.000.000 \\
\hline \multicolumn{3}{|c|}{ Jumlah } & Rp 54.000.000 & \\
\hline
\end{tabular}

4. $\operatorname{AM} 6+4=10$

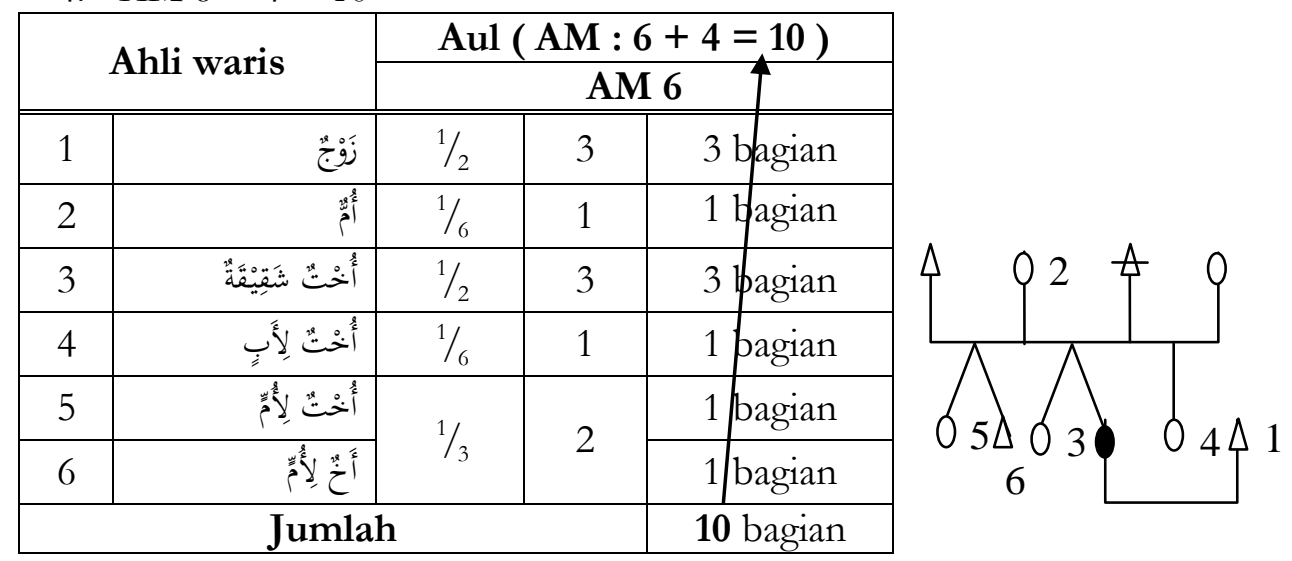

Misalkan HP. Rp 60.000.000 pembagian sebelum dan sesudah teori 'Aul:

a) Sebelum teori ' $a u l: \frac{H P: R p 60.000 .000}{A M: 6}=R p 10.000 .000$

\begin{tabular}{|c|c|c|c|c|}
\hline \multicolumn{2}{|c|}{ Ahli waris } & \multicolumn{2}{|c|}{ Bagian yang seharusnya diterima } & Ket. \\
\hline 1 & زَوْجُج & $3 \times \operatorname{Rp} 10.000 .000$ & Rp 30.000.000 & Bagian pasti \\
\hline 2 & أَمْمُ & $1 \times \operatorname{Rp} 10.000 .000$ & Rp 10.000 .000 & Bagian pasti \\
\hline 3 & أُخْنت شَقَِيْقَةُ & $3 \times \operatorname{Rp} 10.000 .000$ & $\mathrm{Rp} 30.000 .000$ & Bagian pasti \\
\hline 4 & أُ أُخْتُ لِأَبٍ & 1 x Rp 10.000 .000 & Rp 10.000 .000 & Bagian pasti \\
\hline 5 & 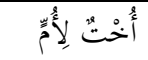 & $1 \times \mathrm{Rp} 10.000 .000$ & Rp 10.000 .000 & Bagian pasti \\
\hline 6 & 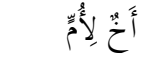 & $1 \times \operatorname{Rp} 10.000 .000$ & Rp 10.000 .000 & Bagian pasti \\
\hline
\end{tabular}

b) Sesudah teori 'aul: $\frac{H P: R p 60.000 .000}{A M: 10}=R p 6.000 .000$

\begin{tabular}{|c|c|c|c|c|}
\hline \multicolumn{2}{|c|}{ Ahli waris } & \multicolumn{2}{|c|}{ Ternyata bagian yang diterima } & Berkurang \\
\hline 1 & زَوْْجُ & $3 \times \operatorname{Rp} 6.000 .000$ & Rp 18.000 .000 & Rp 12.000.000 \\
\hline 2 & أَمٌٌْ & $1 \times \operatorname{Rp} 6.000 .000$ & Rp 6.000 .000 & Rp 4.000.000 \\
\hline
\end{tabular}




\begin{tabular}{|c|c|c|c|c|}
\hline 3 & أُخْتِتُ شَقَقِيَعَةُ & $3 \times \operatorname{Rp} 6.000 .000$ & Rp 18.000.000 & Rp12.000.000 \\
\hline 4 & أُخْْتُ لَأَبٍ & & & 000 \\
\hline 5 & 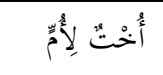 & & & Rp 4.000.000 \\
\hline 6 & 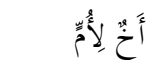 & $1 \times \operatorname{Rp} 6.000 .00$ & $\operatorname{Rp} 6.000 .000$ & Rp 4.000.000 \\
\hline
\end{tabular}

\section{a) Asal Masalah 12}

AM. 12 menerima ' $A u l$ sampai dengan 17 dan hanya angka ganjil. Uriannya

1. $\mathrm{AM} 12+1=13$

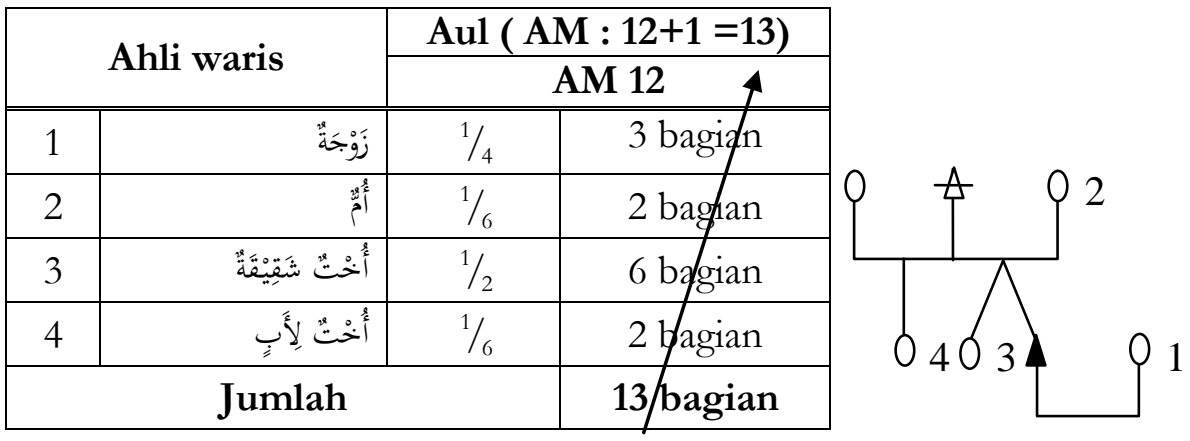

\section{Penjelasan}

Jumlah bagian yang diterima ahli waris adalah 13 bagian menjadi asal masalah (AM) dan asal masalah sebelumnya adalah 12 tidak dipakai.

Misalkan HP. Rp 156.000.000 pembagian sebelum dan sesudah teori ' $A u l$ :

a) Sebelum teori ‘ $a u l: \frac{H P: R p 156.000 .000}{A M: 12}=R p 13.000 .000$

\begin{tabular}{|c|c|c|c|c|}
\hline \multicolumn{2}{|c|}{ Ahli waris } & \multicolumn{2}{|c|}{ Bagian yang seharusnya diterima } & Keterangan \\
\hline 1 & 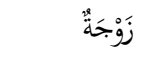 & $3 \times \operatorname{Rp} 13.000 .000$ & Rp 39.000.000 & Bagian pasti \\
\hline 2 & 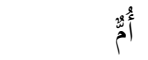 & $2 \times \operatorname{Rp} 13.000 .000$ & Rp 26.000.000 & Bagian pasti \\
\hline 3 & أُخْنِتُ شَقَيْقَقُة & $6 \times \operatorname{Rp} 13.000 .000$ & Rp 78.000.000 & Bagian pasti \\
\hline 4 & أُخْتُ لِأَبٍ & $2 \times \operatorname{Rp} 13.000 .000$ & Rp 26.000.000 & Bagian pasti \\
\hline \multicolumn{3}{|c|}{ Jumlah } & Rp 169.000.000 & \\
\hline
\end{tabular}


b) Sesudah teori 'aul: $\frac{H P: R p 156.000 .000}{A M: 13}=R p 12.000 .000$

\begin{tabular}{|c|c|c|c|c|}
\hline \multicolumn{2}{|c|}{ Ahli waris } & \multicolumn{2}{|c|}{ Ternyata bagian yang diterima } & \multirow{2}{*}{$\frac{\text { Berkurang }}{\text { Rp } 3.000 .000}$} \\
\hline 1 & زَوْجَةٌُ & 3 x Rp 12.000 .000 & Rp 36.000.000 & \\
\hline 2 & أُمُّم & $2 \times \operatorname{Rp} 12.000 .00$ & $\mathrm{Rp}$ & 0.000 \\
\hline 3 & أُخْنت شَقِقِيْعَةُ & $6 \times \operatorname{Rp} 12.000 .000$ & Rp 72.000 .000 & $\operatorname{Rp} 6.000 .000$ \\
\hline 4 & أُخْتِتُ لِأَبِ & $2 \times R p$ & 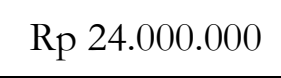 & 00.000 \\
\hline \multicolumn{3}{|r|}{ Jumlah } & .000 & \\
\hline
\end{tabular}

2. $\mathrm{AM} 12+3=15$

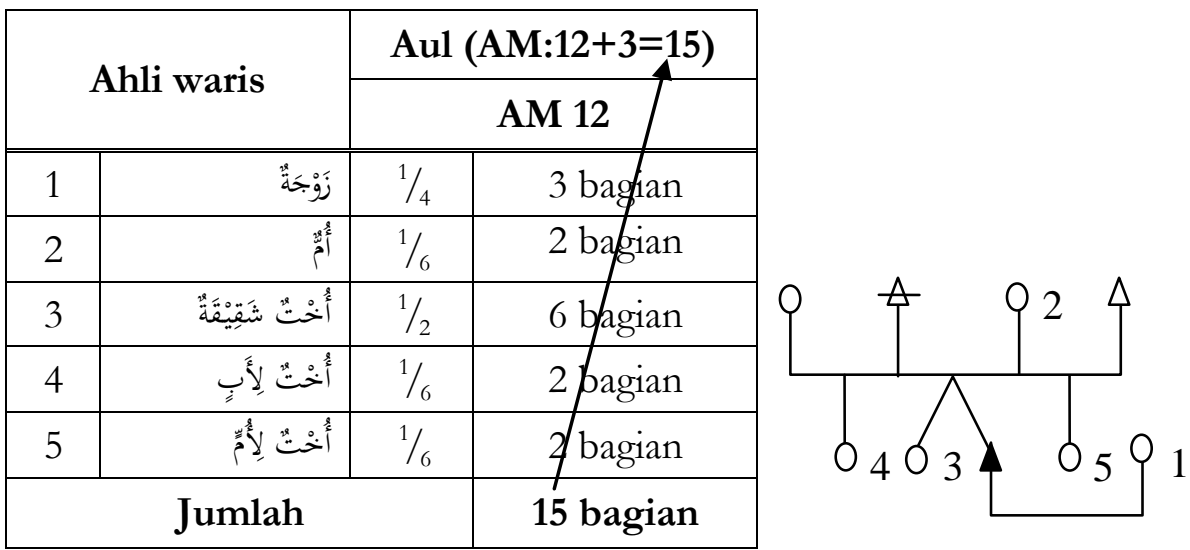

\section{Penjelasan}

Jumlah bagian yang diterima ahli waris, 15 ditetapkan sebagai AM. dan AM. Sebelumnya 12 tidak dipakai

Misalkan harta peninggalan (HP) Rp 180.000.000 maka, pembagian sebelum teori ' $A$ ul harta peninggalan dibagi 12 hasilnya Rp 15.000.000 x dengan bagian yang diperoleh ahli waris. Sedangkan sesudah teori 'Aul harta peninggalan dibagi 15 hasilnya Rp 12.000.000 x dengan bagian yang diperoleh ahli waris.

3. $\mathrm{AM} 12+5=17$

\begin{tabular}{|c|c|c|c|}
\hline \multirow{2}{*}{\multicolumn{2}{|c|}{ Ahli waris }} & \multirow{2}{*}{\multicolumn{2}{|c|}{$\frac{\operatorname{Aul}(\mathrm{AM}: 12+5=17)}{\mathrm{AM} 12}$}} \\
\hline & & & \\
\hline 1 & زَوَْجَةٌ & $1 / 4$ & 3 bagian \\
\hline 2 & 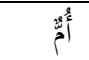 & $1 / 6$ & 2 bagian \\
\hline
\end{tabular}




\begin{tabular}{|c|c|c|c|}
\hline 3 & 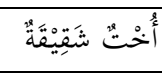 & $1 / 2$ & 6 bagian \\
\hline 4 & 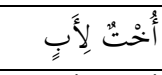 & $1 / 6$ & 2 bagian \\
\hline 5 & 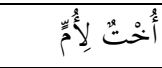 & \multirow{2}{*}{$1 / 3$} & 2 bagian \\
\hline 6 & 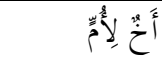 & & 2 bagian \\
\hline \multicolumn{3}{|c|}{ Jumlah } & 17 \\
\hline
\end{tabular}

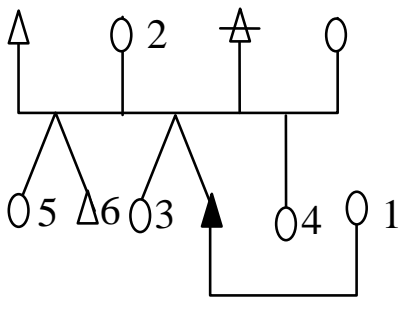

\section{Penjelasan}

Jumlah bagian yang diterima ahli waris adalah 17 menjadi AM. dan AM. sebelumnya yaitu 12 tidak dipakai.

Misalkan harta peninggalan (HP) Rp 105.000.000 maka, pembagian sebelum teori 'Aul harta peninggalan Rp 105.000.000 dibagi 12 hasilnya Rp 17.000.000 x dengan bagian yang diperoleh masing-masing ahli waris, sedangkan sesudah teori 'Aul harta peninggalan Rp 105.000.000 dibagi 17 hasilnya Rp 12.000 .000 x dengan bagian yang diperoleh masing-masing ahli waris

\section{b) Asah Masalah (AM) 24}

AM 24 hanya dapat dinaikan ('Aul) hanya menjadi 27.

\begin{tabular}{|c|c|c|c|}
\hline \multirow{2}{*}{\multicolumn{2}{|c|}{ Ahli waris }} & \multicolumn{2}{|c|}{ Aul (AM:24+3=27) } \\
\hline & & \multicolumn{2}{|c|}{ AM : 24} \\
\hline 1 & زَوْْجَةُ & $1 / 8$ & 3 baghian \\
\hline 2 & أُ أُ & $1 / 6$ & 4 bagian \\
\hline 3 & أَبٌْ & $1 / 6$ & 4 bagian \\
\hline 4 & بنْنتُ & $1 / 2$ & 12 bagian \\
\hline 5 & بِنْتُ ابْنٍ & $1 / 6$ & bagian \\
\hline \multicolumn{3}{|c|}{ Jumlah } & 27 \\
\hline
\end{tabular}

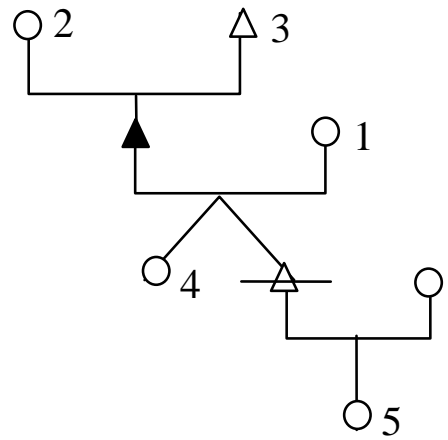

\section{Penjelasan}

Jumlah bagian yang diterima ahli waris 27 menjadi AM. dan AM sebelumnya (24) tidak dipakai.

Misalnya HP. Rp 648.000.000 penyelesaian sebelum dan sesudah teori ' $A u l$ : Misalkan harta peninggalan (HP) Rp 648.000.000 maka, pembagian sebelum teori 'Aul harta peninggalan Rp 648.000 .000 dibagi 24 hasilnya Rp 27.000.000 x dengan bagian yang diperoleh masing-masing ahli waris, sedangkan sesudah teori 'Aul harta 
peninggalan Rp 648.000.000 dibagi 27 hasilnya Rp $12.000 .000 \mathrm{x}$ dengan bagian yang diperoleh masing-masing ahli waris

\section{KESIMPULAN}

Dari paparan di atas dapat disimpulkan sebagai berikut:

Kasus $A$ ul dalam pasal 192 KHI hanya berlaku bagi ahli waris Drawil Furud yaitu ahli waris penerima bagian pasti yang sudah dijelaskan oleh Allah Swt. dalam Al-quran secara definitip

Dalam kasus Aul perolehan masing-masing Drawil Furud berkurang dan berkurang sesuai bagian mereka, sekalipun berkurang nya itu berbeda namun kenyataan berkurangnya itu sama. Karena sama-sama berkurang dan berkurangnya sama itu masih kata gori adil.

Kasus $A u l$ dalam pasal $192 \mathrm{KHI}$ itu masuk dirana fiqih jadi masuk dalam kata gori masalah ijtihadiyyah tetap berpeluang terjadi perbedaan.

\section{DAFTAR PUSTAKA}

Al-'Asqalani, Ibn Hajar. t.th. Bulûgh Al-Marâm. Surabaya: Al-Hidayah.

Al-Bukhāri. t.th. Matn Al-Bukhäri, juz. 4. Singapura: Maktabah wa Mathba'ah Sulaiman.

Al-Fauzani, Salih bin Fauzan bin Abdullah. t.th. Al-Tahqîqah AlMardiyyah Fi Al-Mabâbits Al-Fardiyyah. Beirut: Dar Al-Fikr.

Al-Hadrami, Sa'id bin Said Nabhan. t.th. Tddat Al-Fâridh. Surabaya: Salim Sa'id bin Said Nabhan.

Al-Lahimi, Abd Al-Karim bin Muhammad. 1986. Al-Farâ'idh. Riyadh: Matabah Al-Ma'arif.

Al-Mahâmi, Shabahi Mahmashâni. 1967. Al-Mabâdi Al-Syar'iyyah wa AlQânuniyyah. Beirut: Dar Al-'Tlm.

Al-Marâghi, Ahmad Mustafa. 1974. Tafsìr Al-Maräghi, juz 4.

Al-Razi, Muhammad Fakhruddin. t.th. Tafsìr Fabr Al-Rāzi, Juz 6 dan 11. Beirut: Dar Al-Fikr.

Al-Sahi, Syauqi Abduh. 1988. Ahkâm Al-Mawârits. Damaskus: Dar Hikmah.

Al-Shabuni, Muhammad bin Ali. 1979. Al-Mawârits Fi Al-Syariat AlIslamiyah. Beirut: Dar Al-Fikr.

Al-Suyuti, Jalaluddin. t.th. Al-Dur Al-Mantsur Fi Al-Ta wil bi Al-Ma'tsur. Beirut: Dar Al-Fikr.

Al-Syaukani, Muhammad bin Ali. t.th. Nail Al-Authâr, Juz 8. Beirut: Dar Al-Fikr. 
Al-Zuhayli, Wahbah. 2001. Al-Farầidh wa Al-Mawârits wa Al-Washâya. Damaskus: Dar Al-Qalam.

Badawi, Syansuri. t.th. 'Ilm Al-Mawârits. Jombang: Tebuireng.

Departemen Agama Republik Indonesia. 1971. Al-Qur'an dan Terjemahannya. Jakarta: Yayasan Penyelenggara / Penterjemah AlQur'an.

Makhluf, Muhammad Husen. 1976. Al-Mawârits Fi Al-Syarîah AlIslâmiyyah. Riyadh: Matba'ah Al-Madani.

Muhyidin, Abd Al-Hamid. 1984. Abkâm Al-Mawârits Fi Al-Syariah AlIslâmiyyah 'Ala Madhbab Al-A 'imah Al-Arba'ah. Beirut: Dar AlFikr.

Muslim, Musthafa. 1992. Mabâhits Fi Tlm Al-Mawârits. Jeddah: Dar AlMunarah.

Musthafa. 2004. Al-Rababiyyah Tlm Al-Farâidh. Damaskus: Dar Al-Qalam. Quthub, Sayyid. 2001. Tafsì fi Zhiläl Al-Qur'an, Al-Mujallad Awwal dan Tsani. Beirut: Dar Al-Syuru'. 